Wahana Didaktika Vol. 17 No.1 Januari 2019 : 106-118

\title{
PENULISAN KARANGAN ARGUMENTASI DENGAN STRATEGI HERRINGBONE DAN KEMAMPUAN BERPIKIR KRITIS MAHASISWA
}

\author{
Oleh: Dian Nuzulia Armariena, Liza Murniviyanti \\ (Dosen Universitas PGRI Palembang) \\ Email:dianarera@yahoo.com
}

\begin{abstract}
Abstrak
Penelitian ini bertujuan mengetahui pengaruh penggunaan strategi herringbone dan kemampuan berpikir kritis terhadap kemampuan menulis karangan argumentasi. Yang menjadi sampel dalam penelitian ini adalah mahasiswa Semester IIIa Program Studi Pendidikan Bahasa dan Sastra Indonesia. Teknik analisis data dalam penelitian ini menggunakan program SPSS dan dianalisis dengan uji-T dan anova. Berdasarkan hasil pengujian hipotesis terhadap penelitian yang telah dilakukan, diketahui bahwa penggunaan strategi herringbone dan kemampuan berpikir kritis mahasiswa secara bersama-sama memiliki pengaruh yang positif terhadap kemampuan menulis karangan argumentasi mahasiswa. Hal ini dibuktikan dari hasil uji anova yang menunjukkan $F_{\text {hitung }}$ adalah sebesar 12,34, sedangkan $F_{\text {tabel }}$ untuk taraf 5\% adalah sebesar 3,26 dan untuk taraf 1\% adalah sebesar 5,25. Dengan demikian, dapat disimpulkan bahwa strategi herringbone dan kemampuan berpikir memiliki pengaruh terhadap kemampuan menulis karangan argumentasi mahasiswa.
\end{abstract}

Kata Kunci: Strategi Herringbone, Kemampuan Berpikir Kritis, dan Menulis Karangan Argumentasi

\section{WRITING ARGUMENTATION REQUIREMENTS WITH HERRINGBONE STRATEGIES AND STUDENT CRITICAL SKILLS}

\begin{abstract}
This study aims to determine the effect of the use of herringbone strategies and the ability to think critically about the ability to write arguments. The samples in this study were Semester IIIa Indonesian Language and Literature Education Study Program. The data analysis technique in this study used the SPSS program and was analyzed by T-test and ANOVA. Based on the results of hypothesis testing on the research that has been conducted, it is known that the use of herringbone strategies and students' critical thinking abilities together have a positive influence on the ability to write essays on student arguments. This is evidenced from the results of the ANOVA test which shows Fcount is 12.34, while Ftable for the level of $5 \%$ is 3.26 and for the level of 1\% is 5.25. Thus, it can be concluded that herringbone strategy and thinking ability have an influence on the ability to write essays on student arguments.
\end{abstract}

Keywords: Herringbone Strategy, Critical Thinking Ability, and Writing Argument Essay 


\section{A. PENDAHULUAN}

Menulis dianggap sebagai keterampilan tersulit karena menuangkan pikiran menjadi tulisan adalah kegiatan yang tidak mudah dilakukan. Menulis merupakan aktivitas memindahkan bentuk lisan ke dalam bentuk tulisan. Orang yang terampil berbicara seperti berpidato maupun berceramah, belum tentu memiliki kemahiran yang sama ketika ia menuangkan pidato atau ceramahnya dalam bentuk tulisan. Hal ini disebabkan bahasa tulis dengan bahasa lisan memiliki perbedaan.

Dalam berbahasa lisan, pembicara dapat mengungkapkan yang terdapat di pikirannya secara lebih bebas. Hal terpenting dalam kegiatan berbicara adalah pendengar yang mampu mengerti yang diungkapkan oleh pembicara. Dalam kegiatan menulis, seorang penulis harus memiliki kemampuan menggambarkan yang ingin dibicarakannya kepada pembaca. Pilihan kata dan susunan kalimat yang digunakannya harus tepat dan dapat membuat pembacanya ikut membayangkan dan merasakan untuk memahami maksud penulis tersebut (Tarigan, 2008:21-22).

Berdasarkan survei yang dilakukan Suparno dan Yunus (2009:1.4), ditemukan bahwa aspek pembelajaran bahasa yang paling tidak disukai oleh siswa adalah menulis. Hal ini disebabkan ketidaktahuan siswa terhadap yang harus ditulisnya sehingga siswa selalu menganggap bahwa menulis adalah pelajaran yang sulit. Guru hanya memberikan tema karangan yang harus dituliskan oleh siswa tanpa mengajarkan cara menulis kepada siswa. Berdasarkan tema karangan yang diberikan oleh guru, siswa harus membuat sebuah kerangka karangan sebelum menuliskan karangan mereka. Hal inilah yang sulit dilakukan oleh siswa karena membuat kerangka karangan membutuhkan kemampuan berpikir yang baik.

Keterampilan menulis tidak dapat dipisahkan dari kemampuan berpikir, khususnya berpikir kritis (D'Angelo, 1980:4). Kegiatan menulis justru akan membantu seseorang agar dapat berpikir lebih kritis. Tarigan (2008:22) juga menyatakan bahwa menulis dapat memudahkan siswa untuk berpikir, khususnya berpikir kritis.

Dalam menulis sebuah karangan argumentasi, penulis memerlukan data dan 
fakta yang kemudian ditambahkan dengan pendapat penulis tersebut. Proses penulisan ini memerlukan pemikiran kritis penulis tersebut. Oleh karena itu, proses menulis karangan argumentasi tidak dapat dilepaskan dari keterampilan berpikir kritis (Armariena, 2015:370).

Dalam pembelajaran menulis ada lima jenis karangan yang harus diajarkan yaitu deskripsi, narasi, argumentasi, persuasi, dan eksposisi. Dari kelima jenis karangan tersebut, karangan argumentasi merupakan karangan yang paling berhubungan dengan tingkat kekritisan penulis. Seperti yang dikatakan oleh Keraf (2007:3) “...argumentasi adalah suatu bentuk retorika yang berusaha untuk mempengaruhi sikap dan pendapat orang lain, agar mereka itu percaya dan akhirnya bertindak sesuai dengan apa yang diinginkan oleh penulis atau pembicara".

Dalam pembelajaran di kelas, mahasiswa cenderung kurang mampu membuat karangan argumentasi dengan benar, misalnya, lebih cenderung menyukai materi menulis karangan narasi dan deskripsi karena dirasakan lebih mudah. Hal ini berdasarkan pengamatan peneliti di kelas, mahasiswa cenderung bosan ketika menulis, khususnya menulis karangan argumentasi. Hal ini disebabkan siswa kesulitan untuk menuangkan pendapatnya dalam bentuk tulisan. Mereka lebih suka menulis karangan narasi dan deskripsi karena kedua jenis karangan tersebut lebih banyak menggunakan imajinasi dalam menulis dibandingkan dengan karangan argumentasi yang lebih banyak membutuhkan fakta dan pendapat.

Ketika mahasiswa tersebut menuliskan karangan argumentasi, diperoleh hasil yang kurang baik. Permasalahan yang ada adalah urutan ide pokok yang tidak beraturan antarparagraf. Paragraf pertama yang seharusnya berisi informasi mengenai yang akan dibahas, justru berisi penyebab permasalahan itu terjadi. Selain itu, karangan argumentasi yang dibuat oleh mahasiswa kurang memuat banyak pendapat, padahal karangan argumentasi seharusnya berisi lebih banyak pendapat. Selain itu, karangan yang dibuat oleh mahasiswa tidak memiliki informasi yang lengkap, misalnya karangan hanya berfokus pada apa yang terjadi saja. 
Permasalahan lain adalah kesulitan mahasiswa dalam menuliskan pendapat mereka mengenai suatu fakta padahal karangan argumentasi adalah karangan yang membutuhkan banyak pendapat penulis. Untuk mengatasi masalah tersebut, strategi yang sebaiknya digunakan harus dapat membantu mahasiswa mengeluarkan pendapat, membuat urutan ide pokok dengan tepat, serta menghasilkan karangan yang lengkap yaitu strategi herringbone. Hal ini sejalan dengan pendapat Armariena (2015:371) meyatakan bahwa proses menulis terutama menulis argumentasi memerlukan strategi yang tepat sehingga memudahkan siswa mengeluarkan pendapat, membuat urutan ide pokok dengan tepat serta menghasilkan karangan yang lengkap.

Strategi herringbone merupakan strategi pembelajaran yang dapat membantu mahasiswa dengan kerangka kerja untuk membuat ide utama (Tugwell, 2008:19). Strategi herringbone dapat digunakan pada setiap keterampilan berbahasa, termasuk keterampilan menulis. Strategi ini membuat mahasiswa terlebih dahulu mencari pokok-pokok masalah yang akan mereka tulis. Pokokpokok masalah tersebut berisi enam pertanyaan, yaitu apa, siapa, mengapa, kapan, bagaimana, dan di mana. Dengan membuat enam pertanyaan tersebut, tulisan yang dihasilkan akan lebih terarah dan mencakup seluruh inti masalah. Selain itu, strategi herringbone juga dapat dimodifikasi sesuai dengan kebutuhan karangan yang ditulis. Misalnya untuk membuat karangan narasi, keenam pertanyaan tersebut difokuskan pada yang dilihat dan dirasakan oleh penulis saja.

Strategi herringbone juga berkaitan dengan berpikir kritis mahasiswa. Ketika membuat fishbone yang berisi enam pertanyaan tersebut, mahasiswa harus berpikir kritis untuk mencari jawabannya. Semakin banyak dan beragam jawabannya, semakin baik pula hasil tulisan mahasiswa karena fishbone itulah yang akan dijadikan kerangka karangan menulis. Jadi, berpikir kritis mahasiswa dapat diasah dengan menggunakan strategi herringbone.

Berdasarkan latar belakang, masalah penelitian ini dapat dirumuskan sebagai adalah apakah terdapat pengaruh penggunaan strategi herringbone dan kemampuan berpikir kritis terhadap kemampuan menulis karangan argumentasi. Secara umum, penelitian ini bertujuan untuk mengetahui dan memperoleh 
gambaran terhadap pengaruh penggunaan strategi herringbone dan kemampuan berpikir kritis terhadap kemampuan menulis karangan argumentasi.

Kemampuan berpikir tidak dapat dilepaskan perannya dari pendidikan, khususnya pendidikan bahasa Indonesia. Dalam materi menulis, misalnya, seorang mahasiswa harus memiliki kemampuan berpikir yang baik agar dapat menghasilkan karangan yang sempurna. Dalam menulis sebuah karangan, kemampuan berpikir yang dibutuhkan adalah berpikir kreatif dan berpikir kritis.

Karangan argumentasi adalah "Suatu bentuk retorika yang berusaha untuk mempengaruhi sikap dan pendapat orang lain, agar mereka itu percaya dan akhirnya bertindak sesuai dengan apa yang diinginkan oleh penulis atau pembicara" (Keraf, 2007:3). Karangan argumentasi dapat berisi penjelasan, pembuktian, alasan, maupun ulasan objektif yang disertai rangkaian fakta. Tujuan penulisan karangan argumentasi adalah menyakinkan pembaca bahwa ide, gagasan, serta pendapat tersebut benar dan terbukti.

\section{B. METODOLOGI PENELITIAN}

Metode yang digunakan dalam penelitian ini adalah metode eksperimen semu. Penelitian ini dilakukan untuk memperoleh jawaban dari hipotesis yang telah disusun. Hal ini mengacu pada pendapat Sevilla, dkk. (1993:93) bahwa metode eksperimen adalah metode penelitian yang dapat menguji hipotesis mengenai hubungan sebab-akibat, serta merupakan pendekatan yang paling sahih dalam memecahkan masalah, baik secara praktis maupun secara teori. Pada penelitian eksperimen ini menggunakan desain penelitian one group pretest posttest design.

Tes yang terdapat dalam penelitian ini adalah tes kemampuan menulis karangan argumentasi. Karangan argumentasi siswa dinilai berdasarkan kisi-kisi yang telah ditentukan. Kisi-kisi instrumen kemampuan menulis karangan argumentasi dapat dilihat pada tabel berikut.

Tabel 1 Kisi-kisi Instrumen Kemampuan Menulis Karangan Argumentasi

\begin{tabular}{|l|l|c|}
\hline No. & \multicolumn{1}{|c|}{ Aspek yang dinilai } & Skor maksimal \\
\hline 1 & Organisasi isi & 20 \\
\hline 2 & Isi Karangan & 15 \\
\hline
\end{tabular}


Penulisan Karangan Argumentasi....(Dian Nuzulia Armariena, Liza Murniviyanti)

\begin{tabular}{|l|c|c|}
\hline No. & Aspek yang dinilai & Skor maksimal \\
\hline 3 & Teknik & 10 \\
\hline \multicolumn{2}{|c|}{ Jumlah Skor } & 45 \\
\hline
\end{tabular}

Instrumen kemampuan menulis karangan argumentasi telah disusun berdasarkan kriteria dari berbagai teori yang disesuaikan dengan variabel yang dimaksud. Pengujian instrumen kemampuan menulis karangan argumentasi dilakukan dengan reliabilitas rating. Penilaian dilakukan oleh dua orang penilai, yaitu peneliti.

Instrumen yang digunakan untuk mengumpulkan data kemampuan menulis karangan argumentasi ini berbentuk tes tertulis, yaitu tes menulis karangan argumentasi. Mahasiswa diminta menulis sebuah karangan argumentasi yang telah ditentukan topiknya oleh peneliti. Untuk menilai hasil tulisan mahasiswa, terlebih dahulu ditentukan aspek-aspek penilaiannya. Penilaian yang dilakukan mengacu pada komponen-komponen sesuai kisi-kisi yang telah dijabarkan.

\section{HASIL PENELITIAN DAN PEMBAHASAN}

\section{Deskripsi Data}

Tes dalam penelitian ini berupa unjuk kerja, yaitu mahasiswa diperintahkan menulis sebuah karangan argumentasi lebih kurang 100 kata. Pada tes awal, mahasiswa diminta untuk menulis sebuah karangan argumentasi dengan tema "Penggunaan Kendaraan Bermotor oleh Mahasiswa yang Belum Mempunyai SIM." Tema yang diberikan bervariasi pada setiap pertemuan.

\section{Pengujian Persyaratan Analisis}

Sebelum menganalisis data, perlu dilakukan pengujian sebaran sampel. Pengujian sebaran sampel dilakukan untuk mengetahui normalitas sampel. Dengan demikian hasil penelitian ini akan lebih baik karena uji normalitas ini dilakukan untuk menguji keabsahan sampel. Uji normalitas data dilakukan untuk mendeteksi disribusi data dalam suatu variabel yang digunakan dalam penelitian. Uji normalitas sampel menggunakan teknik Kolmogorov-Smirnov.

Uji homogenitas dilakukan untuk mengetahui variasi sampel yang diambil dari populasi yang sama. Uji homogenitas sampel penelitian ini menggunakan Uji F. 


\section{Uji Normalitas Nilai Menulis Karangan Argumentasi}

Uji normalitas dilakukan pada tes awal. Tes awal kemampuan menulis karangan argumentasi adalah kemampuan menulis yang dimiliki siswa sebelum proses pembelajaran berlangsung. Kemampuan awal menulis karangan argumentasi merupakan rata-rata dari skor tes unjuk kerja menulis karangan argumentasi.

a) Hasil Pretes \& Postes Menulis Karangan Argumentasi

Table 3 Analisis Pretes dan Postes Menulis Karangan Argumentasi Paired Samples Statistics

\begin{tabular}{|c|c|c|c|c|c|}
\hline & & Mean & $\mathrm{N}$ & Std. Deviation & $\begin{array}{l}\text { Std. Error } \\
\text { Mean }\end{array}$ \\
\hline \multirow[t]{2}{*}{ Pair 1} & $\begin{array}{l}\text { Postes Kemampuan } \\
\text { Menulis Kelas Eksperimen }\end{array}$ & 32,389 & 36 & 8,7514 & 1,4586 \\
\hline & $\begin{array}{l}\text { Pretes Kemampuan } \\
\text { Menulis Kelas Eksperimen }\end{array}$ & 17,000 & 36 & 2,8284 & 0,4714 \\
\hline
\end{tabular}

Paired Samples Correlations

\begin{tabular}{|ll|c|c|c|}
\hline & & $\mathrm{N}$ & Correlation & Sig. \\
\hline Pair 1 & $\begin{array}{l}\text { Postes Kemampuan Menulis Kelas } \\
\text { Eksperimen \& Pretes Kemampuan } \\
\text { Menulis Kelas Eksperimen }\end{array}$ & 36 & 0,452 & 0,006 \\
\hline
\end{tabular}

Berdasarkan tabel di atas, signifikansi berada pada 0,000. Hal ini menunjukkan bahwa terdapat kenaikan yang signifikan dari kedua data tersebut. Selain itu, terlihat jelas bahwa terdapat peningkatan skor antara tes awal dan tes akhir menulis karangan argumentasi siswa kelas eksperimen. Skor rata-rata siswa ketika tes awal adalah 17,00, sedangkan ketika tes akhir adalah 32,389. Selisih antara tes awal dan tes akhir adalah sebesar 15,389.

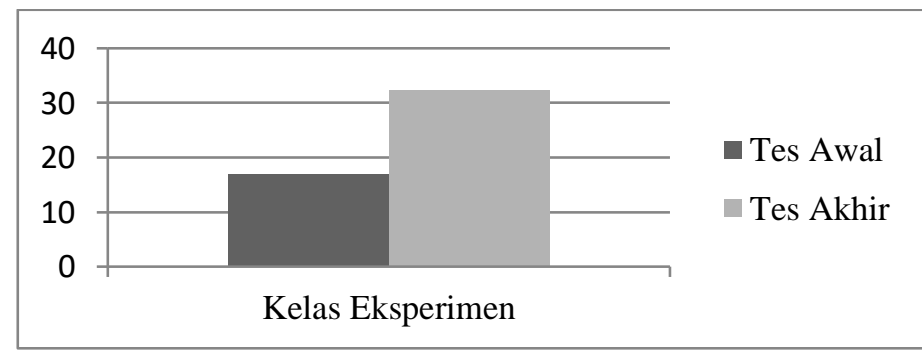

Gambar 1 Perbandingan Skor Menulis Karangan Argumentasi

a. Uji Homogenitas Menulis Argumentasi dan Kemampuan Berpikir Kritis 
Uji homogenitas dilakukan pada tes awal menulis karangan argumentasi dan kemampuan berpikir kritis mahasiswa. Pengujian dilakukan menggunakan Uji F yangterdapat pada program SPSS 17. Uji homogenitas dilakukan untuk mengetahui variasi sampel yang diambil dari populasi yang sama.

\section{Tabel 4 Uji Homogenitas Menulis Argumentasi dan Kemampuan Berpikir Kritis}

Descriptive Statistics

\begin{tabular}{|l|c|c|c|c|c|}
\hline & $\mathrm{N}$ & Mean & $\begin{array}{c}\text { Std. } \\
\text { Deviation }\end{array}$ & Minimum & Maximum \\
\hline $\begin{array}{l}\text { Tes Awal Kemampuan } \\
\text { Menulis Argumentasi } \\
\begin{array}{l}\text { Berpikir Kritis } \\
\text { Mahasiswa }\end{array}\end{array}$ & 36 & 17,000 & 2,8284 & 12,0 & 24,5 \\
\hline
\end{tabular}

Test Statistics

\begin{tabular}{|l|c|c|}
\hline & Tes Awal Kemampuan Menulis & Berpikir Kritis \\
\hline Chi-Square & $11,500^{\mathrm{b}}$ & $9,000^{\mathrm{c}}$ \\
Df & 18 & 17 \\
Asymp. Sig. & 0,872 & 0,940 \\
\hline
\end{tabular}

Berdasarkan tabel signifikansi di atas, ditemukan bahwa signifikansi kemampuan berpikir kritis mahasiswa adalah 0,940. Taraf signifikansi yang digunakan adalah $\alpha=0,05$ dengan kriteria pengujian: Jika nilai sig. lebih besar dari $\alpha=0,05$, data bersifat homogen. Jadi data skor berpikir kritis mahasiswa bersifat homogen.

Sama halnya dengan kemampuan berpikir kritis, taraf signifikansi yang digunakan adalah $\alpha=0,05$ dengan kriteria pengujian: Jika nilai sig. lebih besar dari $\alpha=0,05$. Berdasarkan tabel tersebut, ditemukan bahwa signifikan kemampuan menulis karangan argumentasi mahasiswa adalah 0,872 sehingga menunjukkan bahwa skor menulis karangan argumentasi mahasiswa bersifat homogen.

\section{b. Pengujian Hipotesis}

Pengujian hipotesis dilakukan setelah data menulis argumentasi dan berpikir kritis menunjukkan hasil yang normal dan homogen dianalis menggunakan anova. Hipotesis menguji adakah pengaruh strategi herringbone dan berpikir kritis 
terhadap kemampuan menulis karangan argumentasi mahasiswa. Hipotesis ini menguji tiga sampel secara bersama-sama. Hal pertama yang dilakukan adalah membandingan kemampuan menulis karangan argumentasi kedua data, yaitu pretest dan posttest. Sebelum membandingan kedua data tersebut, masing-masing dibagi menjadi dua kelompok berpikir kritis, yaitu kelompok berpikir kritis tinggi dan kelompok berpikir kritis rendah.

Tabel 5 Data Perbandingan Kemampuan Menulis Karangan Argumentasi Dua Kelompok Berpikir Kritis

\begin{tabular}{|c|c|c|}
\hline No. & BK Tinggi & BK Rendah \\
\hline 1 & 43,5 & 38,5 \\
\hline 2 & 41 & 40,5 \\
\hline 3 & 43 & 32 \\
\hline 4 & 39 & 34 \\
\hline 5 & 44,5 & 31 \\
\hline 6 & 43,5 & 30 \\
\hline 7 & 41 & 32 \\
\hline 8 & 35,5 & 29,5 \\
\hline 9 & 36 & 32 \\
\hline 10 & 38 & 27 \\
\hline $\mathrm{n}$ & 10 & 10 \\
\hline$\Sigma$ & 405 & 326,5 \\
\hline $\mathrm{X}$ & 40,5 & 32,65 \\
\hline $\mathrm{S}$ & 3,24 & 4,09 \\
\hline $\mathrm{S}^{2}$ & 10,5 & 16,73 \\
\hline
\end{tabular}

Tabel 6 Tabel Perhitungan Anova Kemampuan Berpikir Kritis

\begin{tabular}{|c|c|c|c|c|c|c|}
\hline \multirow{2}{*}{ No. } & \multicolumn{2}{|c|}{ BKT } & \multicolumn{2}{c|}{ BKR } & \multicolumn{2}{c|}{ Jumlah } \\
\cline { 2 - 7 } & $\mathbf{X}_{\mathbf{1}}$ & $\mathbf{X}_{\mathbf{1}}{ }^{\mathbf{2}}$ & $\mathbf{X}_{\mathbf{2}}$ & $\mathbf{X}_{\mathbf{2}} \mathbf{2}^{\mathbf{2}}$ & $\mathbf{X}$ & $\mathbf{X}^{\mathbf{2}}$ \\
\hline 1 & 43,5 & 1892,25 & 38,5 & 1482,25 & 82 & 3374,5 \\
\hline 2 & 41 & 1681 & 40,5 & 1640,25 & 81,5 & 3321,25 \\
\hline 3 & 43 & 1849 & 32 & 1024 & 75 & 2873 \\
\hline 4 & 39 & 1521 & 34 & 1156 & 73 & 2677 \\
\hline 5 & 44,5 & 1980,25 & 31 & 961 & 75,5 & 2941,25 \\
\hline 6 & 43,5 & 1892,25 & 30 & 900 & 73,5 & 2792,25 \\
\hline 7 & 41 & 1681 & 32 & 1024 & 73 & 2705 \\
\hline 8 & 35,5 & 1260,25 & 29,5 & 870,25 & 65 & 2130,5 \\
\hline 9 & 36 & 1296 & 32 & 1024 & 68 & 2320 \\
\hline 10 & 38 & 1444 & 27 & 729 & 65 & 2173 \\
\hline$\Sigma$ & $\mathbf{4 0 5}$ & $\mathbf{1 6 4 9 7}$ & $\mathbf{3 2 6 , 5}$ & $\mathbf{1 0 8 1 0 , 7 5}$ & $\mathbf{7 3 1 , 5}$ & $\mathbf{2 7 3 0 7 , 7 5}$ \\
\hline \multicolumn{3}{|c|}{$\mathbf{n}_{\mathbf{1}}=\mathbf{1 0}$} & \multicolumn{3}{|c|}{$\mathbf{n}_{\mathbf{2}}=\mathbf{1 0}$} & \multicolumn{2}{|c|}{$\mathbf{2 0}$} \\
\hline
\end{tabular}


Berdasarkan perhitungan melalui tabel di atas, selanjutnya dilakukan perhitungan (Sugiyono, 2012:201-202).

1. $\mathrm{JK}_{\mathrm{tot}}=\sum X_{\text {tot }}{ }^{2}-\frac{\left(\sum x_{\text {tot }}\right)^{\mathrm{z}}}{N}=27.307,75-26754,6=553,14$

2. $\mathrm{JK}_{\mathrm{ant}}=\frac{\left(\sum x_{1}\right)^{2}}{n_{1}}+\frac{\left(\sum x_{2}\right)^{2}}{n_{2}}+-\frac{\left(\sum x_{\text {tot }}\right)^{2}}{N}$

$$
\begin{aligned}
& =16402,5+10660,2-26.754,6 \\
& =308,2
\end{aligned}
$$

3. $\mathrm{JK}_{\mathrm{dal}}=\mathrm{JK}_{\mathrm{tot}}-\mathrm{JK}_{\mathrm{ant}}=553,14-308,2=224,94$

4. $\mathrm{MK}_{\mathrm{ant}}=\frac{I K_{\text {ant }}}{m-1}=154,1$

5. $\quad \mathrm{MK}_{\mathrm{dal}}=\frac{J K_{\text {daI }}}{N-m}=224,94 / 18=12,49$

6. $\mathrm{F}_{\mathrm{h}}=\frac{M K_{\text {ant }}}{M K_{\text {dal }}}=154,1 / 12,49=12,34$

Hasil yang didapat melalui perhitungan-perhitungan sebelumnya dimasukkan ke dalam ringkasan anova untuk menguji hipotesis tersebut. Tabel ringkasan tersebut adalah sebagai berikut.

\begin{tabular}{|c|c|c|c|c|c|c|}
\hline $\begin{array}{l}\text { Sumber } \\
\text { Variasi }\end{array}$ & dk & $\begin{array}{l}\text { Jumlah } \\
\text { Kuadrat }\end{array}$ & MK & $\mathbf{F}_{\mathbf{h}}$ & $F_{\text {tab }}$ & Ket. \\
\hline Total & 39 & 553,14 & - & \multirow{3}{*}{12,34} & \multirow{3}{*}{$\begin{array}{l}5 \%=3,26 \\
1 \%=5,25\end{array}$} & \multirow{3}{*}{$\begin{array}{c}\mathrm{F}_{\mathrm{h}}>\mathrm{F}_{\mathrm{tab}}=\mathrm{Ha} \\
\text { diterima } \\
12,34>3,26 \\
12,34>5,25\end{array}$} \\
\hline $\begin{array}{c}\text { Antar- } \\
\text { kelompok }\end{array}$ & 3 & 308,2 & 154,1 & & & \\
\hline $\begin{array}{c}\text { Dalam } \\
\text { kelompok }\end{array}$ & 36 & 224,94 & 12,49 & & & \\
\hline
\end{tabular}

Tabel 7 Ringkasan Anova untuk Menguji Hipotesis k Sampel

Berdasarkan tabel rangkuman anova di atas, ditemukan nilai $\mathrm{F}_{\text {hitung }}$ adalah sebesar 12,34 dan $\mathrm{F}_{\text {tabel }}$ sebesar 3,26 untuk taraf kesalahan 5\% dan 5,25 untuk taraf kesalahan 1\%. Dengan syarat $F_{\text {hitung }}>F_{\text {tabel}}$, Ho diterima dan Ha ditolak. Jadi kesimpulannya terdapat perbedaan yang signifikan antara kemampuan menulis karangan argumentasi yang diajarkan dengan strategi herringbone baik untuk kesalahan $5 \%$ maupun $1 \%$.

\section{PEMBAHASAN}


Pengumpulan data berupa hasil kemampuan menulis karangan argumentasi mahasiswa di lapangan yang mulai dilakukan mulai tanggal 16 September-11 Oktober 2018. Selanjutnya, tes awal dan tes akhir menulis karangan argumentasi dilakukan terhadap mahasiswa semester IIIa. Sebelum dilakukan tes akhir, mahasiswa diberi pembelajaran menulis karangan argumentasi sebagai latihan sebanyak dua kali pertemuan. Tes awal dan tes akhir ini dianalisis untuk menguji hipotesis penelitian yang telah ditetapkan.

Uji prasyarat merupakan langkah pertama dalam pengujian hipotesis. Uji prasyarat meliputi uji normalitas dan uji homogenitas. Data kelompok ini dianalisis menggunakan Kolmogorov-Smirnov dan uji $F$ yang terdapat dalam program SPSS 17. Setelah dilakukan uji normalitas dan uji homogenitas, dilakukan pengujian terhadap hipotesis penelitian ini.

Uji normalitas yang dilakukan pada skor berpikir kritis dan skor tes awal menulis karangan argumentasi. Hasil uji normalitas secara keseluruhan menunjukkan bahwa data bersifat normal. Kemampuan berpikir kritis mahasiswa di atas taraf signifikansi 0,05 yaitu pada taraf 0,539. Begitu pula dengan kemampuan menulis karangan argumentasi yang berada di atas 0,05 yaitu 0,433. Uji homogenitas pada kedua data menunjukkan hasil yang positif. Hal ini terlihat dari hasil uji $\mathrm{F}$ yang telah dilakukan, menunjukkan angka 0,875 untuk skor menulis karangan argumentasi dan 0,940 untuk skor berpikir kritis.

Berdasarkan hasil uji T yang dilakukan terhadap strategi herringbone dan kemampuan menulis karangan argumentasi mahasiswa, dapat disimpulkan bahwa strategi herringbone memiliki pengaruh yang positif. Untuk menyimpulkan hal tersebut, pertama-tama dilakukan analisis terhadap hasil pretes-postes menulis karangan argumentasi. Analisis ini menghasilkan kesimpulan bahwa terdapat peningkatan yang signifikan dari skor pretes ke skor postes. Hal ini dilakukan untuk melihat seberapa besar perbedaan kenaikan yang dialami oleh mahasiswa saat pretest dan postest. Hasil yang diperoleh adalah 0,025. Dengan memperhatikan kriteria pengujian, yaitu nilai signifikan $<0,05$ maka disimpulkan bahwa penggunaan strategi herringbone memiliki pengaruh pada kemampuan menulis karangan argumentasi mahasiswa. 
Berpengaruhnya strategi herringbone dengan kemampuan menulis karangan argumentasi sejalan dengan fungsi kerangka ikan yang digunakan dalam penerapan strategi herringbone. Kerangka ikan ini digunakan untuk memfokuskan apa yang ingin ditulis dalam sebuah karangan. Dalam karangan argumentasi yang memerlukan banyak fakta dan pendapat, penggunaan kerangka ikan sangat tepat. Selain dapat membantu memfokuskan tulisan, dengan menuliskan topik karangan pada setiap cabang dikerangka ikan juga dapat membantu mahasiswa mengeluarkan lebih banyak pendapat.

Pengujian hipotesis selanjutnya dilakukan untuk melihat pengaruh antara kemampuan berpikir kritis terhadap kemampuan menulis karangan argumentasi. Sebelum dilakukan pengujian hipotesis, terlebih dahulu dilakukan pembagian kelompok. Kelompok yang dibagi ini berdasarkan skor yang diperoleh melalui angket berpikir kritis. Setiap kelas memiliki dua kelompok, yaitu kelompok yang kemampuan berpikir kritisnya tinggi dan kelompok yang kemampuan berpikir kritisnya rendah. Cara pembagiannya adalah dengan mengambil $27 \%$ dari N, yaitu 9,72 siswa yang kemudian dibulatkan menjadi 10 siswa.

Setelah dilakukan pengujian dengan sampel 10 orang tersebut, diperoleh hasil bahwa kelompok tinggi memiliki taraf sig. (2-tailed) sempurna, yaitu 0,000. Hal ini menunjukkan bahwa mahasiswa yang memiliki kemampuan berpikir kritis tinggi lebih baik dalam menulis karangan argumentasi. Pengujian yang sama dilakukan pada 10 siswa dari kelompok berpikir kritis rendah. Hasil yang diperoleh menunjukkan hasil yang sama dengan kelompok berpikir kritis tinggi, yaitu bertaraf signifikansi 0,000 . Selanjutnya tiap-tiap kelompok digabungkan untuk melihat seberapa besar perbedaan antara kelompok berpikir kritis tinggi dan rendah. Hasilnya menunjukkan signifikansi 0,010. Angka ini berada di bawah taraf probability 0,05 . Jadi tingkat berpikir kritis mahasiswa dapat mempengaruhi kemampuannya dalam menulis karangan argumentasi.

\section{SIMPULAN}

Secara keseluruhan, kemampuan menulis karangan argumentasi mahasiswa lebih baik dibandingkan tanpa penggunaan strategi herringbone. Selain itu, 
kelompok mahasiswa yang berpikir kritis tinggi memiliki kemampuan menulis karangan argumentasi yang lebih baik dibandingkan mahasiswa yang memiliki daya berpikir rendah. Hal ini menunjukkan bahwa tingkat berpikir kritis mahasiswa sangat mempengaruhi kemampuan menulis karangan argumentasi mahasiswa. Strategi pembelajaran dan berpikir kritis memberi pengaruh yang signifikan terhadap kemampuan menulis karangan argumentasi mahasiswa.

\section{DAFTAR PUSTAKA}

Armariena, D. N. (2015). Pengaruh Strategi Herringbone dan Kemampuan Berpikir Kritis terhadap Kemampuan Menulis Karangan Argumentasi Siswa Kelas VII SMP Negeri 45 Palembang. Jurnal Dosen Universitas PGRI Palembang.

Armariena, D. N. (2017). Penulisan Narasi Mahasiswa dengan Metode Copy teh Master dalam Menghidupkan Kartakter, Perilaku dan Konflik Tokoh. Prosiding Dosen Universitas PGRI Palembang Edisi 9, 10-19. Palembang: Universitas PGRI Palembang.

D’Angelo, F. J. (1980). Process and Thought in Composition. Cambridge: Winthrop Publisher Inc.

Keraf, G. (2007). Argumentasi dan Narasi. Jakarta: Gramedia.

Sevilla, C. G., Ochave J. A., Punsalan T. G., Regala B. P., dan Uriarte G. G. (1993). Pengantar Metode Penelitian. (Alimuddin Tuwu, Trans.). Jakarta: Penerbit Universitas Indonesia.

Suparno dan Yunus M. (2009) Keterampilan Dasar Menulis. Jakarta: Universitas Terbuka.

Tarigan, H. G. (2008). Menulis: Sebagai Suatu Keterampilan Berbahasa. Bandung: Angkasa.

Tugwell, H. (2008). Differential EL Strategies: How to Differentiate for Language Proficiency to Teach Core Content to All English Learners. Oakland: Oakland Unified School District. 